\title{
Advances in Genetics and QTL Mapping In Carrot (Daucus Carota L.)
}

\author{
Selvakumar $\mathbf{R}^{1 *}$ and Pritam Kalia ${ }^{2}$ \\ ${ }^{1}$ Central Institute of Temperate Horticulture, India \\ ${ }^{2}$ Indian Agricultural Research Institute, India
}

Submission: September 24, 2018; Published: February 27, 2019

${ }^{*}$ Corresponding author: Selva Kumar R, ICAR-Central Institute of Temperate Horticulture, Srinagar, Jammu and Kashmir, India

\section{Mini Review}

Carrot (Daucus carota $\mathrm{L} ., 2 \mathrm{n}=2 \mathrm{X}=18 ; 1 \mathrm{C}=473 \mathrm{Mb}$ ) is a cool weather crop grown in temperate and subtropical regions for its edible storage tap roots both for fresh as well as processed vegetable throughout the world and is most important of all the root crops [1-3]. It has been classified as 'poor man's gingeng' due to its rich $\beta$-carotene and tocopherol with health promoting properties [4-5]. It led to increasing awareness to the consumer consumption and nutritional industry to make natural products rich in carotenoids and anthocyanins [6]. Carrot has naturally wide genetic diversity due to its natural single locus mutations, natural hybridization of its wild relatives and ancestors followed by human selection [7-8]. The natural allele collection of carrot includes dominant alleles such as A ( $\boldsymbol{\alpha}$-carotene accumulation), Io (intense orange xylem, which may be an allelic form of $A$ ), $L_{1}$ and $L_{2}$ (lycopene accumulation), $O$ (orange xylem, which may also be an allelic form of A) as well as the recessives alleles y (yellow xylem) and rp (reduced pigmentation). The three dominant loci $\mathrm{Y}_{1} \mathrm{Y}_{1}$, and $\mathrm{Y}_{2}$ control differential distribution of $\boldsymbol{\alpha}$ and $\boldsymbol{\beta}$-carotene in xylem/ phloem tissue. The $Y_{2}$ mutant controls low carotene content of the storage root xylem ("core") in high carotene orange backgrounds [8]. Laferriere et al. [9] demonstrated that in yellow $\times$ white cross, white colour was dominant over yellow which was controlled by a single dominant gene. Moreover, they reported that three dominant genes were responsible for the absence of pigmentation in white $\times$ orange crosses. Light orange colour has also been shown to be dominant to orange [10]. Kust [11] postulated three dominant alleles $Y_{,} Y_{1}$ and $Y_{2}$ which prevented the formation of orange colour in root xylem tissue. Buish et al. (1979) characterized the effects of the series of $Y$ alleles on carotenoid content in phloem and xylem. The $\mathrm{Y}$ and $\mathrm{Y}_{2}$ allele were governing white pigmentation of root which was dominant to orange (yy).

Laferriere et al. [9] hypothesized that single major gene was governing white colour root of yellow $\times$ white crosses which three major genes were determining the white and orange. Further, research studies showed that two major genes in one cross and four major genes in orange $\times$ yellow cross. Simultaneously, Imam et al.
[10] reported that lemon (light yellow) was dominant over light orange in lemon $\times$ light orange whereas light orange was dominant over orange in light orange $\times$ orange. Kust [11] described that dominant alleles of three genes $\left(\mathrm{Y}_{1} \mathrm{Y}_{1}\right.$ and $\left.\mathrm{Y}_{2}\right)$ control the orange colour in the xylem which was epistatic to two pigment enhancing genes $(\mathrm{IO}, 0)$. The orange colour of phloem was governed by pigment enhancing genes $(\mathrm{IO}, 0)$ in equal or higher number without dominant alleles (Y-) and combination of these colour enhancing genes with three dominant allele $\left(\mathrm{Y}_{,} \mathrm{Y}_{1}\right.$ and $\left.\mathrm{Y}_{2}\right)$. Furthermore, he suggested that the genetic constitution of white was recessive at all loci $\left(\mathrm{y}_{1} \mathrm{y}_{1} \mathrm{y}_{2} \mathrm{y}_{2}\right.$ ioiooo). $\beta$-carotene and anthocyanins impart orange/yellow and purple colour to carrot, respectively. The genetic control of carotene synthesis is complex which includes several enhancer genes and inhibitor genes. Kust [11] postulated the dominant $\left(\mathrm{Y}_{2}\right)$ locus control the carotene accumulation in carrot xylem core whereas the recessive $\left(y_{2} / y_{2}\right)$ locus conditioned the $\beta$, and $\gamma$-carotene rich orange xylem core. Furthermore, the dominant heterozygous $\left(\mathrm{Y}_{2}^{-}\right)$possess xanthophyll-rich yellow white core. Therefore, $Y, y$ and $Y_{2}$ loci were more influencing on the amount and distribution of $\alpha$ and $\beta$-carotene in which $Y$ locus blocs the synthesis of $\alpha$ and $\beta$-carotene as well as xanthophylls whereas $y$, and $Y_{2}$ blocks synthesis of carotenes but not xanthophylls [12]. Umiel et al. [13] studied in $\mathrm{F}_{2}$ populations of orange $\times$ red crosses that the inheritance of orange colour was governed by single dominant gene which is epistatic to red colour gene. Furthermore, on the basis biochemical analyses they proposed that 'A' gene for the accumulation of $\alpha$-carotene were originated from orange parent and 'L' gene for lycopene formation were originated from the red parent.

Rhodes [14] in $\mathrm{F}_{2}$ populations of red $\times$ light yellow cross observed segregation of 15: 1 ratio of yellow-orange to red colour. He suggested that two dominant genes conditioning the conversion of lycopene to $\alpha$ and $\beta$-carotene. The white or non-pigmentation of root were conditioned by recessive gene (rp) which controls the $\beta$-carotene synthesis. The mutant gene 'rp' had been identified and characterized, suggesting that it causes $93 \%$ reduction of to- 
tal carotenoids [15]. Moreover, Koch et al. [11] postulated that 'rp' mutant produces more $\alpha$-tocopherol which is provitamin-E.

The dominant gene of $\mathrm{P}_{1}$ confers the purple colour of root which shows only partial variation on roots and it is hypostatic to $\mathrm{P}_{2}$ gene influencing pigmentation in aerial parts of petiole, leaf and floral corolla [8]. Anthocyanin accumulation in the carrot phloem is controlled by $\mathrm{P}_{1}$ locus, with purple $\left(\mathrm{P}_{1}\right)$ dominant to non-purple $\left(\mathrm{p}_{1}\right)$. Although, $\mathrm{P}_{1}$ and $\mathrm{Y}_{2}$ loci were unlinked in $\mathrm{F}_{2}$ and $\mathrm{BC}$ populations to Eastern carrot germplasm $[8,16]$. The purple petiole of Tender Sweet was conditioned by single dominant gene ' $G$ ', dominant to green ' $\mathrm{g}$ ' [17]. Purple colour of root was governed by two complimentary loci in $\mathrm{F}_{1}$ progeny of two non-purple inbreeds [9]. The sugar condition of carrot was governed by single dominant gene (Rs). These genes express more reducing sugars of glucose and fructose in Rs/- plants. In contrast, rs/rs type plants produces more sucrose accumulation [18]. Broad sense heritability estimates have been determined for total dissolved solids $40-45 \%$ [19]. The rs/rs mutant plants has carrot invertase enzyme which knockout the function enzyme [20]. The heritability of nematode resistance (Meloidogyne javanica) was evaluated using the open-pollinated cultivars Brasília as resistant, and Kuronan as tolerant [21].

\section{Quantitative trait loci (QTL) mapping}

The recent development of molecular marker technologies and the use of these markers in detecting and mapping quantitative trait loci has become a powerful approach for studying the genetic and phenotypic basis of complex traits [22-25]. If individual genetic components associated with a complex trait can be identified, then research can focus on the function of each locus independently without the confounding effects of other segregating loci [25].

Bradeen et al. [26] identified six AFLP markers linked to $\mathrm{Y}_{2}$ locus with distance of $2.8 \mathrm{cM}$ and $15.8 \mathrm{cM}$ from $103 \mathrm{~F}_{2}$ populations of a cross B9304 $\times$ YC7262 which segregated for core colour by using bulked segregate analysis [27]. Subsequently, Vivek et al. [28] identified a single AFLP marker from the $Y_{2}$ locus and assigned on linkage group B with size of $2.2 \mathrm{cM}$ by using these population. Moreover, they have identified horticulturally important QTLs through segregation analysis. Santos et al. [29] revealed that 287AFLP markers were mapped by using $160 \mathrm{~F}_{2}$ population of Brasilia $\times$ HCM with character of medium orange and high carotene line, respectively. These markers were associated with $\alpha$ and $\beta$-carotene, lycopene, and the precursor's $\zeta$-carotene and phytoene QTL conditioning each of the traits measured were detected. In total, 8, 3, 1, 4 and 5QTLs were detected for $\alpha$-carotene, $\beta$-carotene, lycopene and the precursors $\zeta$-carotene and phytoene accounting for $40 \%, 20 \%, 7.2 \%, 16.3 \%$ and $28 \%$, respectively of total phenotypic variation whereas QTLs of Brasilia and HCM showed 3.7 to $13.2 \%$ total variation. Twenty major QTL have been identified for orange carrots which control carotenoids content [30]. Buish et al. [12] reported that these QTLs, two major genes ( $Y$ and $Y_{2}$ ) and clusters of genes were involved in common carotenoid biosynthetic pathway from the population of orange carrots $\left(\mathrm{yyy}_{2} \mathrm{y}_{2}\right)$ and white carrots $\left(\mathrm{YYY}_{2} \mathrm{Y}_{2}\right)$ with yellow and pale orange colour.

Santos et al. [29] identified that SNP based markers were closely linked to the $\mathrm{Y}_{2}$ gene whereas as described by Bradeen and Simon (1998) also maps to this region. They considered ZDS2 and ZEP as candidate gene for $Y_{2}$ QTL. Phenotype of yellow (xanthophyll) and the orange ( $\alpha$ - and $\beta$-carotene) were conditioned by $Y_{2}[12]$. They revealed that $Y_{2}$ gene were derived from yellow segregates of B493 $\times$ QAL population. Furthermore, since it maps to this important region, $\mathrm{Y}_{2}$ may be responsible for at least some of the QTL effect observed by Santos et al. [31]. Santos et al. [29] identified quantitative trait loci (QTLs) for total carotenoids affecting the concentration of carotenoids in the ranges from 15.8, $21.7,26.4,37.7$, and $44.2 \%$ of the total phenotypic variance for lycopene, $\alpha$-carotene, $\beta$-carotene, $\zeta$-carotene and phytoene, respectively. Just et al. [32] reported that 22 genes which involved in the carotenoid biosynthesis and metabolism, provided gene-specific codominant polymorphisms for eight of the nine linkage groups. One major QTL has been identified for $\beta$-carotene, total carotene and lycopene accumulation in the $\mathrm{F}_{2}$ population of $\mathrm{P} 50006$ and HCM A.C. by using sequence related amplified polymorphism (SRAP) markers which showed $12.79 \%, 12.87 \%$, and $14.61 \%$ of total phenotypic variations. The SRAP marker were tightly linked in 9 linkage groups in the size of $502.9 \mathrm{cM}$ with a mean interval of $5.5 \mathrm{cM}$. The genetic variability of these three QTLs was due to additive genetic variance. In addition, a pair of epistasis QTL for $\beta$-carotene and lycopene accumulation showed $15.1 \%$ and $6.5 \%$ of total phenotypic variation, respectively. These SRAP markers linked to these QTLs could be used in selection or QTL pyramiding for high carotenoids and lycopene content in carrot breeding [33].

All five anthocyanin glycosides as well as root total pigment estimate (RTPE) differed quantitatively in the $\mathrm{F}_{2}$ population. For the purpose of QTL analysis, a high resolution gene-derived SNPbased linkage map of carrot was constructed with 894 markers covering $635.1 \mathrm{cM}$ with a $1.3 \mathrm{cM}$ map resolution. A total of 15 significant QTL for all anthocyanin pigments and for RTPE mapped to six chromosomes. Eight QTL with the largest phenotypic effects mapped to two regions of chromosome 3 with co-localized QTL for several anthocyanin glycosides [34,35]. Ellison et al. [36] developed two closely linked codominant markers, 4135Apol ${ }_{1}$ and 4144ApeKI, to more accurately select $\mathrm{y}_{2} \mathrm{y}_{2}$ plants with increased $\beta$-carotene accumulation. These markers have been tested not only within the mapping population, but also in a group of unrelated genetic materials, and have proven to be very accurate in predicting orange and no orange phenotypes. Further they identified that the single large effect QTL on the distal arm of chromosome 7 overlapped with the previously identified $\beta$-carotene accumulation QTL, $Y_{2}$. Fine mapping efforts reduced the genomic region of interest to $650 \mathrm{~kb}$ including 72 genes [36].

This review briefly discussed about genetics and QTL mapping approaches in carrot for different carotenoids such as $\alpha$-carotene, 
$\beta$-carotene, $\gamma$-carotene, lutein and different anthocyanin pigments. It will help the carrot breeders to understand the genetic mechanism of different traits, application of molecular markers and to map the targeted nutritional content. Furthermore, recent development of genomic resources and genome sequence data will help the carrot improvement efforts and help to identify additional candidate genes underlying different carrot nutritional accumulation in carrots.

\section{References}

1. Arumuganathan K, Earle ED (1991) Nuclear DNA content of some important plant species. Plant Mol Biol Rep 9(3): 208-218.

2. Bennett MD, Leitch IJ (1995) Nuclear DNA amounts in Angiosperms. Ann Bot 76: 113-176.

3. Iorizzo M, Senalik DA, Grzebelus D, Bowman M, Cavagnaro PF, et al. (2011) De novo assembly and characterization of the carrot transcriptome reveals novel genes, new markers, and genetic diversity. BMC Genomics 12: 389.

4. Hashimoto T, Nagayama T (2004) Chemical composition of ready-to eat fresh carrot. J Food Hyg Soc 39: 324-328.

5. Hager T], Howard LR (2006) Processing effects on carrot phytonutrients. Hort Sci 41: 74-79.

6. Arscott SA, Tanumihardjo SA (2010) Carrots of many colors provide basic nutrition and bioavailable phytochemicals acting as a functional food. Compr Rev Food Sci Food Saf 9(2): 223-239.

7. Gabelman WH, Peters S (1979) Genetical and plant breeding possibilities for improving the quality of vegetables. Acta Hort 93: 243259.

8. Simon PW (1996) Inheritance and expression of purple and yellow storage root color in carrot. J Heredity 87(1): 63-66.

9. Laferriere L, Gabelman WH (1968) Inheritance of color, total carotenoids, alpha carotene, and beta-carotene in carrots (Daucus carota L.) Proc Amer Sot Hort Sci 93: 408-418.

10. Imam MK, Gabelman WH (1968) Inheritance of carotenoids in carrots, Daucus carota L. Proc Amer Sot Hort Sci 93: 419-428.

11. Koch T, Goldman IL (2005) Relationship of carotenoids and tocopherols in a sample of carrot root-color accessions and carrot germplasm carrying $R p$ and $r p$ alleles. J Agri Food Chemi 53(2): 325-331.

12. Buishand JG, Gabelman WH (1979) Investigations on the inheritance of color and carotenoid content in phloem and xylem of carrot roots (Daucus carota L.). Euphytica 28(3): 611-632.

13. Umiel N, Gabelman WH (1972) Inheritance of root color and carotenoid synthesis in carrot (Daucus carota L.): orange vs. red. J Amer Sot Hort Sci 97: 453-460.

14. Rhodes BB (1973) Biosynthesis of alpha- and beta-carotene in roots and tops of Daucus carota L. PhD Thesis, Kansas State Univ.: pp.59.

15. Goldman IL, Breitbach DN (1996) Inheritance of a recessive character controlling reduced carotenoid pigmentation in carrot (Daucus carota L.). J Hered 87(5): 380-382

16. Selvakumar R (2016) Genetic studies for economic traits and molecular mapping for anthocyanin content in carrot (Daucus carota L.). PhD Thesis, ICAR-Indian Agricultural Research Institute, New Delhi.

17. Angell FF, Gabelman WH (1970) Inheritance of purple petiole in carrot, Daucus carota var. sativa. Hort Sci 5: 175-176.

18. Freeman RE, Simon PW (1983) Evidence for simple genetic control of sugar type in carrot (Daucus carota L.). J Amer Soc Hort Sci 108: 50-54.
19. Stommel JR, Simon PW (1989) Phenotypic recurrent selection and heritability estimates for total dissolved solids and sugar type in carrot. J Amer Soc Hort Sci 114: 695-699.

20. Yau Y, Simon PW (2003) A 2.5-kb insert eliminates acid soluble invertase isozyme II transcript in carrot (Daucus carota L.) roots, causing high sucrose accumulation. Plant Mol Biol 53(1-2): 151-162.

21. Huang SP, Delia PT, Vecchia, Ferreira PE (1986) Varietal response and estimates of heritability of resistance to Meloidogyne javanica in carrots. J Nematology 18(4): 496-501.

22. Edwards LH, Ketata H, Smith EL (1976) Gene action of heading date, plant height, and other characters in two winter wheat crosses. Crop Sci 16(2): 275-277.

23. Edwards MD, Stuber CW, WendelJF (1987) Molecular marker facilitated investigations of quantitative trait loci in maize. I. Numbers, genomic distribution and types of gene action. Genetics 116(1): 113-125.

24. Paterson AH, Lander E, Hewitt JD, Peterson S, Lincoln SE, et al. (1988) Resolution of quantitative traits into Mendelian factors by using a complete linkage map of restriction fragment length polymorphisms. Nature 335 (6192): 721-726.

25. Williams JGK, Kubelik AR, Livak KJ, Rafalski JA, Tingey SV (1990) DNA polymorphisms amplified by arbitrary primers are useful as genetic markers. Nucleic Acids Res 18(22): 6531-6535.

26. Bradeen JM, Simon PW (1998) Conversion of an AFLP fragment linked to the carrot Y2 locus to a simple, codominant, PCR based marker form. Theor Appl Genet 97(5-6): 960-967.

27. Michelmore RW, Paran I, Kesseli RV (1991) Identification of markers linked to disease resistance genes by bulked-sergeants analysis; a rapid method to detect markers in specific genomic regions by using segregating populations. Proc Natl Acad Sci 88(21): 9828-9832.

28. Vivek BS, Simon PW (1999a) Linkage relationships among molecular markers and storage root traits of carrot (Daucus carota L. ssp. sativus). Theor Appl Genet 99(1-2): 58-64.

29. Santos CAF, Simon PW (2002) QTL analyses reveal clustered loci for accumulation of major provitamin A carotenes and lycopene in carrot roots. Mol Genet Genom 268(1): 122-129.

30. Santos CAF, Simon PW (2002) Some AFLP amplicons are highly conserved DNA sequences mapping to the same linkage groups in two $\mathrm{F}_{2}$ populations of carrot. Genet Mol Biol 25(2): 195-201.

31. Santos CAF, Simon PW (2004) Merging carrot linkage groups based on conserved dominant AFLP markers in $\mathrm{F}_{2}$ populations. J Am Soc Hort Sci 129: 211-217.

32. Jinks JL, Jones RM (1958) Estimation of the components of heterosis. Genetics 43(2): 223-234.

33. Ou CG, Deng BT, Bao SY, Zhao ZW, Hu H et al. (2010). QTL mapping for contents of main carotenes and lycopene in carrot (Daucus carota L.) Yi Chuan 32(12): 1290-1295.

34. Cavagnaro PF, Chung SM, Manin S, Yildiz M, Ali A et al. (2011) Microsatellite isolation and marker development in carrot-genomic distribution, linkage mapping, genetic diversity analysis and marker transferability across Apiaceae. BMC Genomics 12: 386.

35. Cavagnaro PF, Iorizzo M, Yildiz M, Senalik D, Parsons J et al. (2014) A gene-derived SNP-based high resolution linkage map of carrot including the location of QTL conditioning root and leaf anthocyanin pigmentation. BMC Genomics 15: 1118.

36. Ellison S, Senalik D, Bostan H, Iorizzo M, and Simon P (2017) Fine Mapping, transcriptome analysis, and marker development for $Y_{2}$, the gene that conditions $\beta$-carotene accumulation in carrot (Daucus carota L.). G3 (Bethesda) 7(8): 2665-2675. 
This work is licensed under Creative

Commons Attribution 4.0 License

DOI: 10.19080/JOJHA.2018.01.555585

\section{Your next submission with Juniper Publishers} will reach you the below assets

- Quality Editorial service

- Swift Peer Review

- Reprints availability

- E-prints Service

- Manuscript Podcast for convenient understanding

- Global attainment for your research

- Manuscript accessibility in different formats ( Pdf, E-pub, Full Text, Audio)

- Unceasing customer service

Track the below URL for one-step submission https://juniperpublishers.com/online-submission.php 